\title{
Does inadequate luteal function limit the establishment of pregnancy in the early post-partum ewe?
}

\author{
Jacqueline M. Wallace, J. J. Robinson and R. P. Aitken
}

The Rowett Research Institute, Greenburn Road, Bucksburn, Aberdeen AB2 9SB, UK

\begin{abstract}
Summary. In Exp. 1 the effect of lactation versus early weaning on luteal function was examined in seasonally anoestrous Finn Dorset ewes that were induced to ovulate at $21(\mathrm{~N}=14)$ or $35(\mathrm{~N}=14)$ days post partum by using a CIDR device and PMSG. Prolactin concentrations were significantly higher $(P<0.001)$ in lactating compared with early weaned ewes throughout the study. The proportion of lactating ewes with inadequate luteal function (as assessed by daily progesterone concentrations) in the 21-day group was 0.43 ( 3 or 7 ) compared with 0.67 ( 4 of 6 ) for those weaned within 2 days after parturition. Corresponding values for the 35-day group were 0 ( 0 of 4$)$ and 0.14 ( 1 of 7) respectively. There was no evidence of abnormal luteal function in standard ewes $(\mathrm{N}=8)$ for which the interval from parturition was $>150$ days.

In Exp. 2 we examined whether pregnancy can be successfully established during the breeding season following transfer of embryos into lactating or early weaned ewes in the early post-partum period. Embryos were donated from Border Leicester $\times$ Scottish Blackface ewes for which the interval from previous parturition was $>150$ days. These embryos were transferred synchronously on Day 5 after behavioural oestrus to recipient ewes with the same breeding history as the donors (standard ewes, $N=15$ ) or to lactating or early weaned recipients that had been induced to ovulate on Day $21(\mathrm{~N}=16)$ or $35(\mathrm{~N}=24)$ post partum. In the 21 -day group inadequate luteal function was observed in 2 of $7(0.28)$ lactating and 4 of $9(0.44)$ early weaned ewes compared with corresponding values of 1 of $13(0.08)$ and 2 of $11(0 \cdot 18)$ in the 35-day post-partum group. Luteal function was normal in all standard ewes. The proportion of successful pregnancies in the standard ewes was 0.80 (12 of 15) compared with 0 in lactating and early weaned ewes in the 21 -day group and 0.08 ( 1 of 13) and 0.36 ( 4 of 11 ) respectively in the 35 -day group.

The incidence of inadequate luteal function is therefore independent of the suckling stimulus and is higher in ewes induced to ovulate on Day 21 than Day 35 post partum during breeding and non-breeding seasons. For early post-partum recipient ewes with normal luteal function it is suggested that the high incidence of pregnancy failure after transfer of embryos may be due to embryo mortality caused by an inappropriate uterine environment or the inability of the embryo to sustain its luteotrophic signal.
\end{abstract}

Keywords: post partum; corpus luteum; embryo transfer; pregnancy; uterus; ewe

\section{Introduction}

The attainment of two lambing cycles per year would radically improve the notoriously low reproductive efficiency of the ewe and partly remove the seasonal nature of sheep meat production. To achieve a 6-monthly lambing cycle ewes must be successfully mated within 35-40 days after parturition. Recent work has shown that the use of laparoscopic insemination to 
deposit semen at the tip of the uterine horn, thus bypassing the involuting uterus, is effective in reducing the interval from parturition to fertilization in lactating ewes (McKelvey et al., 1989; Wallace et al., 1989). However, despite successful fertilization at an induced oestrus 28 days after parturition, no pregnancies were sustained and there was a high incidence of inadequate luteal function in lactating ewes induced to ovulate by using progestagen pessaries and pregnant mares' serum gonadotrophin (PMSG) at pessary withdrawal. Luteal function was classified as inadequate when corpora lutea either failed to secrete progesterone completely, as assessed by twice daily peripheral blood samples, or caused a transient rise in progesterone lasting only $12-36 \mathrm{~h}$. Lactation generally prolongs the duration of post-partum anoestrus (Mauleon \& Dauzier, 1965; Kann \& Martinet, 1975; Shevah et al., 1975; Kann et al., 1977) and is associated with reduced fertility at an induced oestrus during breeding and non-breeding seasons (Restall et al., 1978; Rhind et al., 1980). If a practicable 6-monthly lambing cycle is ever to be achieved, functional corpora lutea would have to be induced during the non-breeding and breeding seasons, preferably whilst the ewes are lactating.

The present experiments were carried out to determine (a) the functional life-span of corpora lutea induced 21 or 35 days after parturition in lactating compared with early weaned ewes during seasonal anoestrus, and (b) whether pregnancy can be successfully established during the breeding season after transfer of embryos into lactating or early weaned ewes in the early post-partum period.

\section{Materials and Methods}

\section{Experiment 1}

Finnish Landrace $\times$ Dorset Horn ewes, aged 2-4 years old, which had been inseminated at a synchronized oestrus were each injected with $15 \mathrm{mg}$ betamethasone (Betsolan, Glaxovet plc, Greenford, Middlesex, UK) on Day 142 of pregnancy to induce parturition. Lambings occurred 36-72 h later between 11 and 13 May, corresponding to seasonal anoestrus. The 28 ewes, average litter size $2 \cdot 3 \pm 0 \cdot 2$, were individually penned at the Rowett Research Institute located at $57^{\circ} \mathrm{N} 2^{\circ} \mathrm{W}$ and were offered a complete diet supplying $9 \mathrm{MJ}$ metabolizable energy/kg dry matter daily.

Immediately after lambing the ewes were allocated evenly to one of four groups ( 7 ewes per group) on the basis of weight, parturition date and litter size. Lambs were weaned within $48 \mathrm{~h}$ of parturition from 14 of the ewes. These four groups were used, in a $2 \times 2$ factorial design, to investigate the effects of early weaning versus suckling and interval to induced ovulation ( 21 versus 35 days post partum) on the subsequent life-span of the corpus luteum. A further 8 ewes (hereafter referred to as standard ewes), for which the interval from previous parturition was in excess of 150 days, were induced to ovulate at the same time as the 21-day $(\mathrm{N}=4)$ and 35 -day $(\mathrm{N}=4)$ post-partum ewes and were included for comparative purposes only. In all ewes synchronization of oestrus was achieved by withdrawing a progesterone-impregnated controlled internal drug release device (CIDR; containing $0.3 \mathrm{~g}$ progesterone; AHI Plastic Moulding Co., Hamilton, New Zealand) 12 days after their insertion. At CIDR withdrawal each ewe received an i.m. injection of 500 i.u. PMSG (Intervet Laboratories P.L.C., Cambridge, UK). Onset of oestrus was assessed by using a vasectomized ram at 4-h intervals between 20 and $68 \mathrm{~h}$ after CIDR withdrawal. Ovulation rates were determined at laparoscopy on Day 7 of the induced oestrous cycle.

Blood samples were taken daily by jugular venepuncture at $09: 00 \mathrm{~h}$ from Day 1 of the study, equivalent to Day 1 post partum, until CIDR withdrawal on Day 19 or 33 depending on treatment group. Samples were taken twice daily at 08:00 and 20:00 h for 20 days, starting $24 \mathrm{~h}$ after onset of oestrus. In addition more frequent samples were taken via a jugular cannula (Braunula, 14G; Dunlop Veterinary Supplies, Dumfries, UK) at 15-min intervals for $12 \mathrm{~h}$ on Day 1 of the induced cycle (oestrus $+24 \mathrm{~h}$ ).

All daily and twice-daily samples were assayed for progesterone and prolactin. Samples taken during the frequent sampling period were assayed for prolactin only.

\section{Experiment 2}

Donor ewes. Border Leicester $\times$ Scottish Blackface ewes for which the interval from previous parturition was $>150$ days were used to donate embryos for transfer into recently-lambed recipients. Synchronization of the donor ewes was achieved by withdrawing progestagen-impregnated pessaries (Chronogest: Intervet) 12 days after their insertion. At pessary withdrawal each ewe received 750 i.u. PMSG. Onsets of oestrus were recorded at 4-h intervals by using a vasectomized ram and all ewes were artificially inseminated at 48,60 and $72 \mathrm{~h}$ after pessary withdrawal with $0.2 \mathrm{ml}$ of a pool of mixed raw semen from a number of rams. On Day 5 of the oestrous cycle the eggs 
were recovered by the standard technique of retrograde flushing (Hunter et al., 1955), held at $37^{\circ} \mathrm{C}$ in ovum culture medium (Flow Laboratories, Irvine, UK) and transferred within $5 \mathrm{~h}$ of recovery to recipients as synchronously as possible.

Recipient ewes. Border Leicester $\times$ Scottish Blackface ewes were induced to lamb, as described in Exp. 1, during the breeding season from 2 to 5 January. Average litter size was $1 \cdot 8 \pm 0 \cdot 1$. Between 48 and $60 \mathrm{~h}$ after parturition the 40 ewes were allocated evenly to one of four groups on the basis of weight, parturition date and litter size. Ewes were synchronized to ovulate, using a CIDR device as described for Exp. 1, at 21 ( 9 early weaned and 7 lactating ewes) or 35 (11 early weaned and 13 lactating ewes) days post partum. Lambs were weaned within $48 \mathrm{~h}$ of parturition in the early weaned groups. A further 15 standard recipient ewes for which the interval from previous parturition was $>150$ days were induced to ovulate alongside the 21 -day $(N=8)$ and 35 -day $(N=7)$ post-partum ewes for comparative purposes to assess the efficiency of the embryo transfer procedure. At withdrawal of the CIDR device all ewes received an i.m. injection of 750 i.u. PMSG. Onset of oestrus was assessed by using a vasectomized ram at 4-h intervals between 20 and $52 \mathrm{~h}$ after CIDR-device withdrawal. At laparotomy on Day 5 of the cycle recipient ewes received $1(\mathrm{~N}=9), 2(\mathrm{~N}=41)$ or $3(\mathrm{~N}=5)$ embryos depending on availability and the numbers of corpora lutea were counted.

All lambs were weaned from lactating ewes on Day 20 of the induced cycle, i.e. on Day 41 or 55 post partum. Ewes diagnosed pregnant by progesterone analysis were X-rayed at Day 90 to determine fetal numbers (Wenham \& Robinson, 1972).

Blood samples were taken daily at 09:00 h from all recipient ewes from Day 1 post partum until 20 days after induction of oestrus. All daily samples were assayed for prolactin and progesterone. After withdrawal of the CIDR device ewes were sampled at 4-h intervals from +24 to $+72 \mathrm{~h}$ to determine the onset time of the preovulatory $\mathrm{LH}$ surge. These samples were assayed for LH only.

\section{Hormone assays}

LH and prolactin were measured in duplicate by specific double-antibody radioimmunoassays as described previously (McNeilly \& Andrews, 1974; McNeilly et al., 1986). The sensitivities of the assays were $0.05 \mathrm{ng} \mathrm{LH}$ (NIADDK-o LH-25)/ml and $0.08 \mathrm{ng}$ prolactin (NIADDK-o PRL-17)/ml. The intra- and inter-assay coefficients of variation were 5.9 and $9.5 \%$ and 5.2 and $10.5 \%$ for $\mathrm{LH}$ and prolactin respectively. Progesterone concentrations were measured in $100 \mu \mathrm{l}$ aliquants of plasma by radioimmunoassay as described by Djahanbahkch et al. (1981). The intraassay coefficient of variation was $12.5 \%$, the detection limit was $0.3 \mathrm{ng} / \mathrm{ml}$ and the recovery of progesterone from plasma was $62 \cdot 9 \pm 1 \cdot 1 \%(n=2000)$.

\section{Statistical analysis}

Unless indicated otherwise the results were analysed by a 2-way classification analysis of variance in which the main effects of number of days post partum and early weaning versus suckling and their interaction were examined. Due to the unequal number of animals in each group the analysis of variance was carried out by regression.

\section{Results}

\section{Experiment 1}

Oestrus and ovulation rate. The proportion of ewes induced to show behavioural oestrus coincident with Day 21 post partum was 0.86 (6 of 7) and 1.0 (7 of 7$)$ for early weaned and lactating groups respectively. Corresponding values at Day 35 post partum were $1.0(7$ of 7$)$ and 0.57 ( 4 of 7 ). All 8 standard ewes showed behavioural oestrus. The mean time of onset of oestrus for ewes induced to show oestrus on Day 35 post partum was shorter $(P<0.05)$ than for those induced to show oestrus on Day 21 post partum (Table 1). All ewes that exhibited oestrous behaviour had evidence of recent ovulation at laparoscopy on Day 7 of the cycle. There were no significant differences in ovulation rate between early weaned and lactacting ewes induced to ovulate 21 or 35 days post partum (Table 1).

Peripheral progesterone concentrations during CIDR synchronization. After insertion of the CIDR-device daily peripheral progesterone concentrations increased immediately as shown in Fig. 1. Thereafter progesterone concentrations decreased with time in all ewes and there were no significant differences between groups in the rate of decrease as assessed by comparing the slopes of the linear regressions of progesterone concentrations against time. Similarly, during synchronization there were no significant differences in peripheral progesterone concentrations in early weaned or 
Table 1. Time to onset of oestrus and ovulation rate in early weaned (EW) and lactating (L) ewes induced to ovulate 21 or 35 days post partum

\begin{tabular}{|c|c|c|c|c|c|c|c|c|}
\hline & \multicolumn{2}{|c|}{$\begin{array}{l}21 \text { days } \\
\text { post partum }\end{array}$} & \multicolumn{2}{|c|}{$\begin{array}{l}35 \text { days } \\
\text { post partum }\end{array}$} & \multirow[t]{2}{*}{ r.s.d.* } & \multicolumn{2}{|c|}{$\begin{array}{l}\text { Significance of } \\
\text { differences }\end{array}$} & \multirow{2}{*}{$\begin{array}{c}\text { Standard } \\
\text { ewes } \\
\text { (mean } \pm \text { s.d.) }\end{array}$} \\
\hline & EW & $\mathrm{L}$ & EW & L & & $\begin{array}{c}\text { Stage } \\
\text { post partum }\end{array}$ & $\mathrm{EW} v \mathrm{~L}$ & \\
\hline No. of ewes & 7 & 7 & 7 & 7 & & & & 8 \\
\hline $\begin{array}{l}\text { No. of ewes showing } \\
\text { behavioural oestrus }\end{array}$ & 6 & 7 & 7 & 4 & & & & 8 \\
\hline Mean onset of oestrus (h) & $36 \cdot 7$ & $41 \cdot 7$ & $33 \cdot 7$ & $36 \cdot 0$ & $5 \cdot 08$ & $P<0.05$ & N.S. & $36 \cdot 5 \pm 6 \cdot 50$ \\
\hline Mean ovulation rate & $1 \cdot 16$ & 1.43 & $1 \cdot 28$ & $2 \cdot 0$ & 0.54 & N.S. & N.S. & $2 \cdot 12 \pm 0 \cdot 62$ \\
\hline
\end{tabular}

*Residual standard deviation.
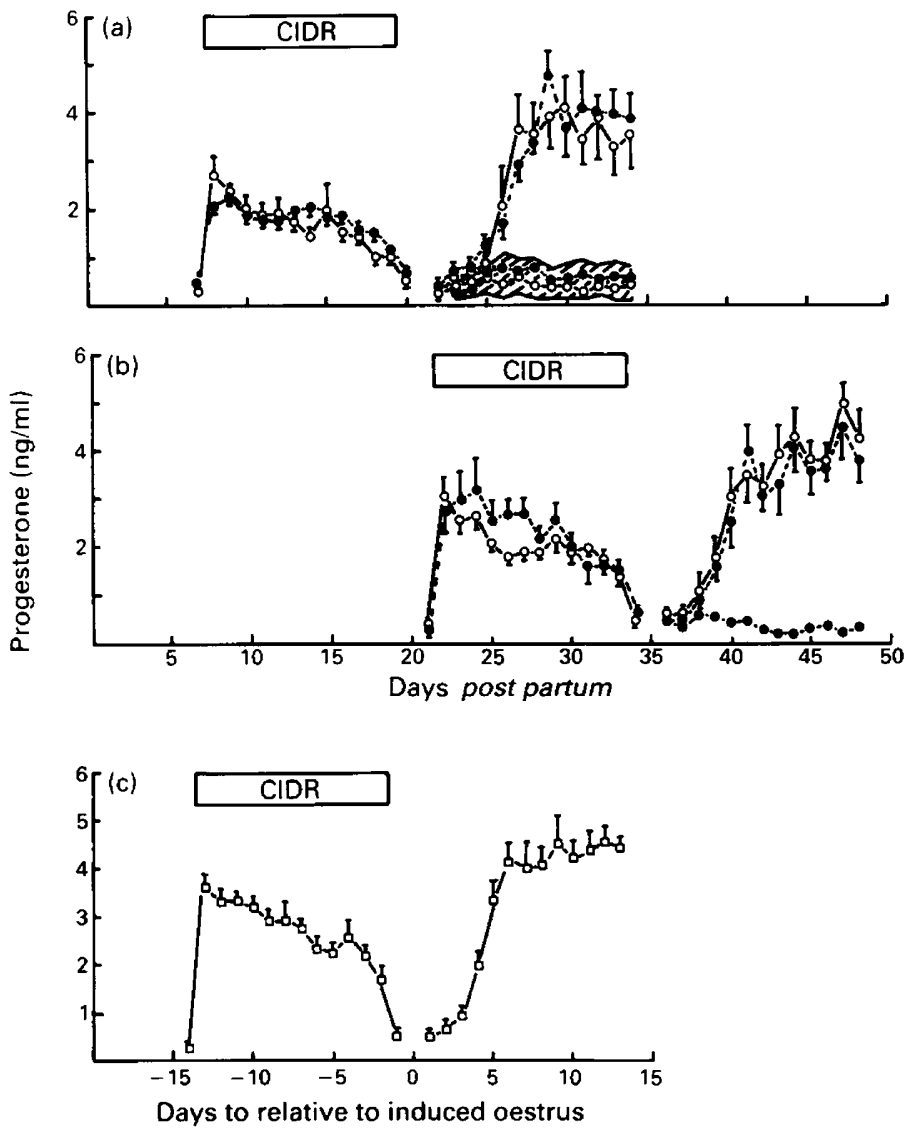

Fig. 1. Progesterone concentrations during and after CIDR-device synchronization of oestrus in early weaned $(N=13,0)$ and lactating $(N=11,0)$ ewes induced to ovulate (a) on Day 21 or (b) Day 35 post partum during seasonal anoestrus. Progesterone concentrations for standard ewes $(\mathrm{N}=8, \mathrm{c})$ induced to ovulate alongside the post-partum groups are included for comparison. Values are mean \pm s.e.m. 


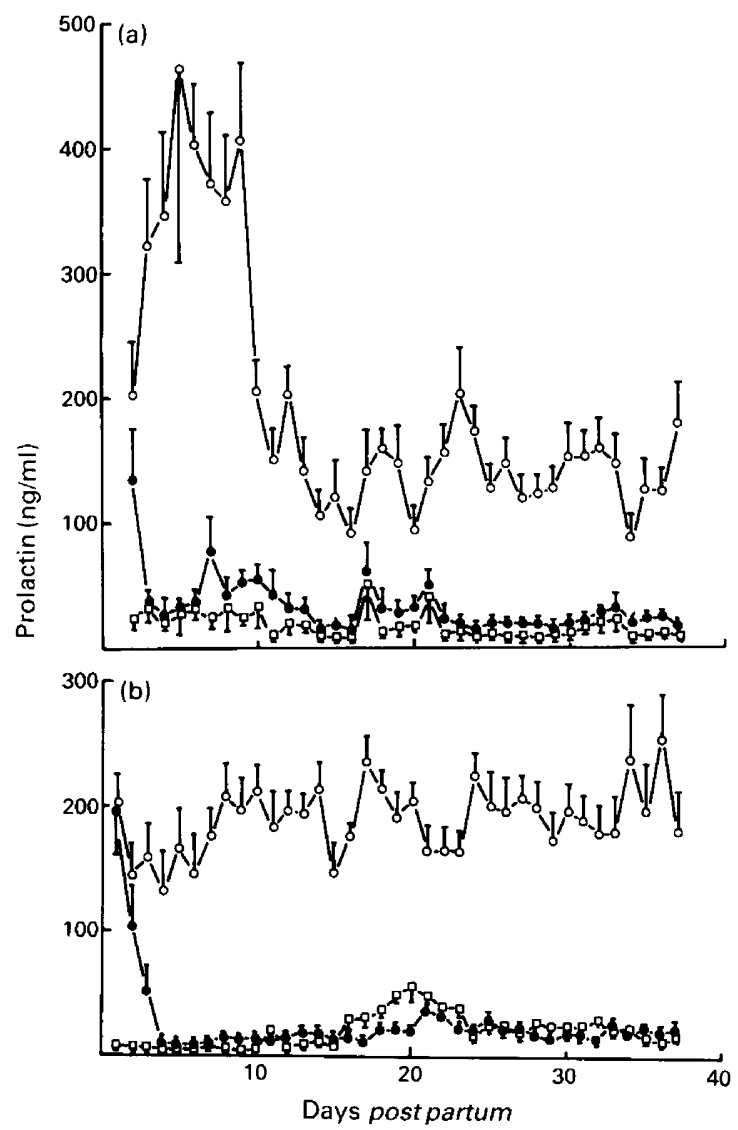

Fig. 2. Changes in daily plasma prolactin concentrations during (a) seasonal anoestrus and (b) breeding season in early weaned $(\bullet)$ and lactating $(O)$ ewes throughout the first 38 days post partum. Standard ewes $(\square)$ for which the interval from previous parturition was $>150$ days are included for comparison. Values are mean \pm s.e.m.

lactating ewes induced to ovulate on Day 21 compared with Day 35 post partum. Progesterone concentrations during synchronization of oestrus in the standard ewes were similar to those of post-partum ewes.

Corpus luteum function. After synchronization of oestrus, the subsequent corpus luteum function was assessed by measuring peripheral progesterone concentrations in twice-daily samples. Normal luteal function was defined as an increase in progesterone concentrations starting within 4 days of behavioural oestrus and rising to exceed $1 \mathrm{ng} / \mathrm{ml}$ for at least 8 days thereafter (based on McLeod et al., 1983). Of the ewes that exhibited behavioural oestrus, the proportion with inadequate luteal function in the 21-day groups was 0.67 (4 of 6 ) for early weaned compared with 0.43 ( 3 of 7 ) for lactating ewes. Corresponding values for the 35-day group were $0 \cdot 14$ ( 1 of 7$)$ and 0 ( 0 of 4) respectively. There was no evidence of abnormal luteal function in any of the standard ewes for which the interval from parturition was $>150$ days. No correlation was found between the uptake of progesterone from the CIDR device, measured as the mean of the daily concentrations in peripheral plasma, and subsequent luteal function from Day 3 to 12 of the luteal phase.

Prolactin. Daily plasma prolactin concentrations throughout the study are illustrated in Fig. 2(a). Plasma prolactin values fell abruptly within $24 \mathrm{~h}$ of lamb removal in all early weaned ewes 
Table 2. Time to onset of oestrus and the preovulatory LH surge, ovulation rate and embryo survival in early weaned (EW) and lactating (L) ewes induced to ovulate and receiving embryos at 21 or 35 days post partum

\begin{tabular}{|c|c|c|c|c|c|c|c|c|}
\hline & \multicolumn{2}{|c|}{$\begin{array}{l}21 \text { days } \\
\text { post partum }\end{array}$} & \multicolumn{2}{|c|}{$\begin{array}{l}35 \text { days } \\
\text { post partum }\end{array}$} & \multirow[t]{2}{*}{ r.s.d.* } & \multicolumn{2}{|c|}{$\begin{array}{l}\text { Significance of } \\
\text { differences }\end{array}$} & \multirow{2}{*}{$\begin{array}{c}\text { Standard } \\
\text { ewes } \\
\text { (mean } \pm \text { s.d. })\end{array}$} \\
\hline & EW & $\mathrm{L}$ & EW & L & & $\begin{array}{c}\text { Stage } \\
\text { post partum }\end{array}$ & $\mathrm{EW} y \mathrm{~L}$ & \\
\hline $\begin{array}{l}\text { No. of ewes showing } \\
\text { behavioural oestrus }\end{array}$ & 9 & 7 & 11 & 13 & & & & 15 \\
\hline Mean onset of oestrus (h) & $31 \cdot 8$ & $37 \cdot 6$ & $31 \cdot 6$ & $36 \cdot 9$ & $7 \cdot 5$ & N.S. & $P<0.025$ & $28.6 \pm 6.20$ \\
\hline Mean ovulation rate & $2 \cdot 33$ & $2 \cdot 86$ & $3 \cdot 27$ & $3 \cdot 31$ & $1 \cdot 39$ & N.S. & N.S. & $2.86 \pm 1.43$ \\
\hline $\begin{array}{l}\text { Mean preovulatory LH } \\
\text { surge onset (h from } \\
\text { CIDR-device } \\
\text { withdrawal) }\end{array}$ & $42 \cdot 4$ & $39 \cdot 8$ & $39 \cdot 3$ & $43 \cdot 1$ & 7.95 & N.S. & N.S. & $38 \cdot 1 \pm 12 \cdot 39$ \\
\hline $\begin{array}{l}\text { Mean no. of embryos } \\
\text { transferred }\end{array}$ & $2 \cdot 0$ & $2 \cdot 0$ & $1 \cdot 8$ & $* 1.9$ & $0 \cdot 57$ & N.S. & N.S. & $1.9 \pm 0.38$ \\
\hline $\begin{array}{l}\text { Proportion of embryos } \\
\text { surviving to term }\end{array}$ & 0 & 0 & $0 \cdot 20$ & 0.04 & $0 \cdot 15$ & $P<0.05$ & N.S. & $0 \cdot 62$ \\
\hline
\end{tabular}

*One ewe did not receive embryos because her corpora lutea were in an advanced stage of regression.

(means \pm s.e.m., Day 2 post partum $135.4 \pm 31.5$ versus Day $3,35.3 \pm 4.6 \mathrm{ng} / \mathrm{ml}(P<0 \cdot 01$, Student's $t$ )). Thereafter daily prolactin concentrations remained low and were similar to those of standard ewes. In contrast, prolactin concentrations in lactating ewes were significantly higher than in early weaned and standard ewes throughout the study $(P<0.001)$ with peak prolactin levels occurring during the first 2 weeks of lactation. Thereafter, prolactin values decreased with time post partum as emphasized by comparing mean prolactin concentrations measured over a 12 -h period on Day 1 (oestrus $\pm 24 \mathrm{~h}$ ) of the induced cycle. In lactating ewes induced to show oestrus on Day 21 post partum therefore, prolactin concentrations were significantly higher $(P<0.05)$ than in ewes induced to show oestrus on Day 35 post partum (mean \pm s.e.m., $198 \pm 6.5$ versus $150 \pm 5 \cdot 0 \mathrm{ng} / \mathrm{ml})$.

\section{Experiment 2}

Oestrus, ovulation and pregnancy rate. Mean times of onset of oestrus were independent of stage post partum but lactating ewes had a significantly longer interval $(P<0.025)$ from withdrawal of the CIDR-device to oestrus than did early weaned ewes. In comparison, the mean onset of oestrus of standard ewes was similar to that of early weaned ewes. The onset of the preovulatory LH surge relative to CIDR-device withdrawal was not significantly different between groups, the overall mean being $40 \cdot 5 \pm 1 \cdot 2 \mathrm{~h}$ (Table 2). All ewes that exhibited oestrous behaviour had evidence of recent ovulation at laparotomy on Day 5 and there were no significant differences in ovulation rate between groups. With the exception of I lactating ewe whose corpora lutea were totally regressed, all ewes received 1, 2 or 3 good quality embryos on Day 5 of the cycle, depending on availability.

The proportion of ewes considered to be pregnant, due to high peripheral progesterone concentrations beyond Day 18 of the induced cycle, in the 21 -day group was 0.11 and 0.28 for early weaned and lactating ewes respectively. Corresponding values for the 35-day group were 0.45 and 0.30 . At radiography on Day 90 none of the early weaned or lactating ewes in the 21 -day group were diagnosed pregnant while the proportions of pregnancies for the 35-day group were 

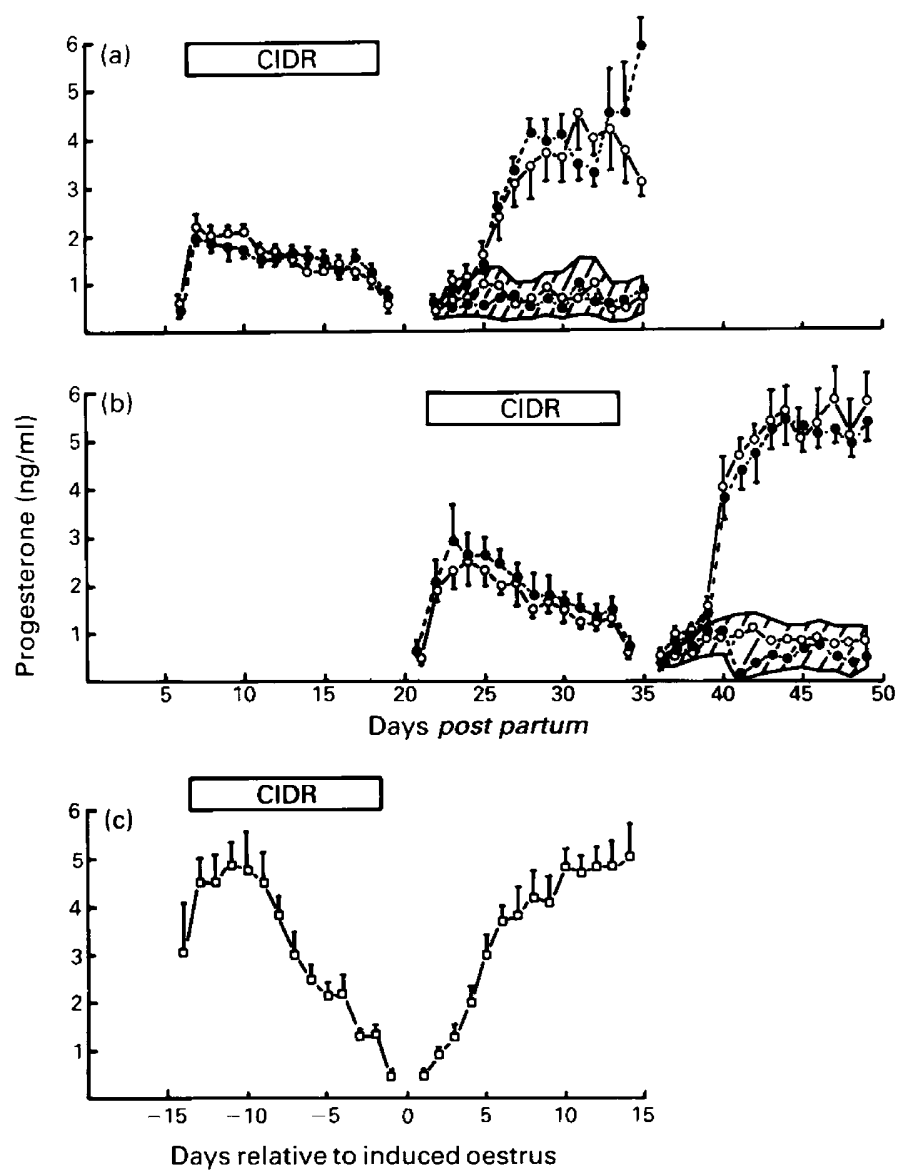

Fig. 3. Progesterone concentrations during and after CIDR-device synchronization of oestrus in early weaned $(\mathrm{N}=20,0)$ and lactating $(\mathrm{N}=20,0)$ ewes induced to ovulate (a) on Day 21 or (b) Day 35 post partum during the breeding season. Progesterone concentrations for standard ewes $(\mathrm{N}=15, \mathrm{c})$ induced to ovulate alongside the post-partum groups are included for comparison. Values are mean \pm s.e.m.

0.36 and 0.08 for early weaned and lactating ewes respectively. For comparison 0.80 (12 of 15) standard ewes were diagnosed pregnant at radiography. Embryo survival at 90 days as a proportion of embryos transferred was 0.20 (4 of 20) and 0.04 (1 of 23) for 35-day early weaned and lactating ewes compared with 0.66 (19 of 29) for standard recipient ewes. One early weaned ewe aborted at Day 83 of gestation. After radiography a further early weaned ewe aborted at Day 91 and a standard ewe at Day 114 of gestation. At parturition there was evidence of embryo loss in the placental membranes of 2 standard ewes and 1 early weaned ewe. There were no significant differences between lamb birthweights of post-partum ewes compared with standard ewes.

Corpus luteum function. Peripheral progesterone concentrations during synchronization with the CIDR device are shown in Fig. 3. Progesterone values were identical in early weaned compared with lactating ewes and were independent of stage post partum. Of the 15 standard ewes 13 were at the mid-luteal stage of a naturally occurring oestrous cycle at the time of insertion of the CIDR device. This invalidated the use of circulating progesterone concentrations for comparing the 

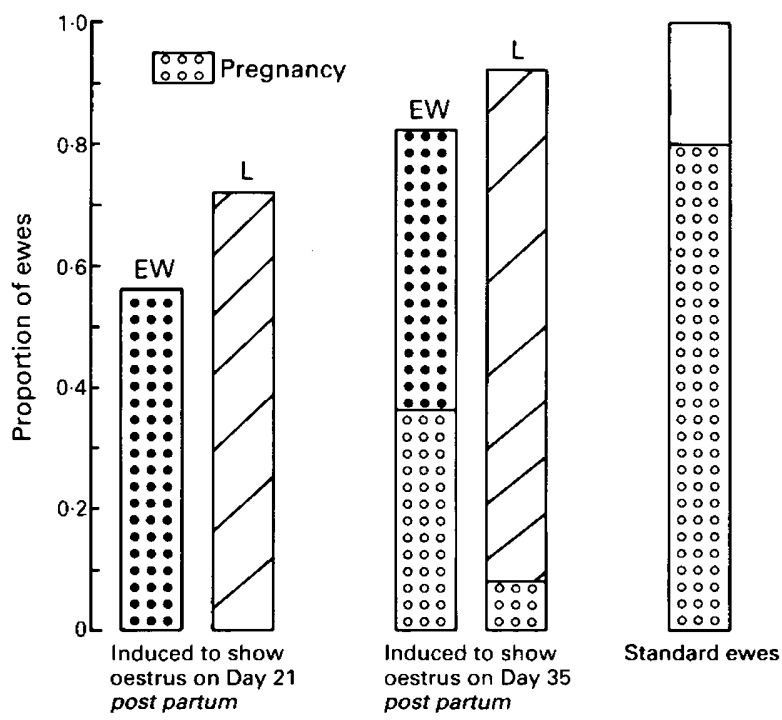

Fig. 4. The proportions of early weaned (EW) and lactating (L) ewes exhibiting normal luteal function after an induced oestrus on Day 21 or 35 post partum. Standard recipient ewes are included to provide a guide to the efficiency of the embryo transfer procedure under ideal conditions.

uptake of progesterone from the CIDR device by the standard ewes with that by the post-partum ewes. Following withdrawal of the CIDR device, the subsequent corpus luteum function was assessed as described for Exp. 1. The proportion of ewes showing normal luteal function in relation to pregnancy rate is shown in Fig. 4. The mean peripheral progesterone concentrations for those ewes with normal luteal function was not significantly different between groups from Days 1 to 14 of the induced cycle and, furthermore, was not correlated with whether pregnancy was established (Figs $3 \& 4$ ). Similarly, no correlation was found between plasma progesterone concentrations during synchronization of oestrus with the CIDR device and subsequent luteal function or pregnancy within post-partum groups. The incidence of inadequate luteal function was higher $(P<0.05)$ in 21 -day (6 of 16$)$ than in 35 -day $(3$ of 24$)$ post-partum ewes. Inadequate luteal function consisted of either no rise in peripheral progesterone concentration after ovulation or a transient increase in progesterone lasting only 1-2 days. The corpus luteum of all these ewes had previously been considered to be regressin $\mathrm{g}$ at the time of surgery on Day 5 of the cycle because of their pale appearance. None of the standard ewes exhibited abnormal luteal function.

Prolactin. Daily plasma prolactin concentrations from Day 0 to 40 post partum are illustrated in Fig. 2(b). Plasma prolactin values fell abruptly within $48 \mathrm{~h}$ of lamb removal in all early weaned ewes and thereafter remained low (mean \pm s.e.m., Day 2 post partum, $107.0 \pm 21.8$ versus Day $4,11.9 \pm 2.2 \mathrm{ng} / \mathrm{ml}, P<0.001$ Student's $t$ ). Prolactin concentrations in lactating ewes were significantly higher $(P<0.001)$ than in early weaned and standard ewes throughout the study.

\section{Discussion}

The results of the present studies show that the use of an intravaginal CIDR device containing progesterone, in conjunction with exogenous gonadotrophin, is highly effective in inducing 
oestrous behaviour and ovulation in the early post-partum ewe during the non-breeding and breeding seasons. This synchronization method was equally as effective at inducing oestrus on Day 21 as Day 35 post partum and was independent of seasonal and lactational effects. Previously, progestagen-impregnated pessaries and exogenous gonadotrophin have been extensively used to induce oestrus in lactating ewes (Cognie et al., 1975; Dawe \& Fletcher, 1976; Cognie \& Pelletier, 1976; Rhind et al., 1977; Quirke et al., 1981) but none of these studies attempted to induce oestrus as early as 21 days post partum. Indeed our own observations (J. M. Wallace \& J. J. Robinson, unpublished observations) suggest that progestagen pessaries form a physical barrier to the passage of detritus originating from the involuting uterus and this may impair absorption of the progestagen from the pessary by the vaginal mucosa. The structure of the CIDR device used in the present studies was observed to permit fluid drainage while in situ and therefore offers considerable advantages over progestagen pessaries in synchronizing early postpartum ewes which are still undergoing uterine involution.

We have confirmed and considerably extended our previous observations (Wallace et al., 1989) that induction of ovulation in the early post-partum ewe is associated with a high incidence of inadequate luteal function. In the present studies the incidence of inadequate luteal function was higher in ewes induced to ovulate on Day 21 than Day 35 post partum during the non-breeding and breeding seasons. Inadequate luteal function following the induction of ovulation, using a variety of hormone treatments, in seasonally anoestrous ewes has largely been attributed to defects in the hormonal priming of the preovulatory follicle and/or luteotrophic support after ovulation (Haresign \& Lamming, 1978; McNeilly et al., 1981; McLeod et al., 1982a, b; Wallace et al., 1986). However, in the present studies subnormal luteal function in post-partum ewes cannot be explained by inadequate progesterone and/or gonadotrophin priming because peripheral plasma progesterone concentrations during CIDR-device synchronization of oestrus were similar to those in standard ewes and were not correlated with subsequent luteal function in any of the treatment groups. Furthermore, we have previously shown that the onset and magnitude of the preovulatory LH and FSH surges in ewes induced to ovulate in the very early post-partum period were not related to subsequent luteal function and were independent of stage post partum (Wallace et al., 1989). However, inadequate luteotrophic support after ovulation cannot be completely ruled out. Alternatively, inadequate luteal function, particularly in ewes induced to ovulate on Day 21 post partum, may arise because of an increased release of and/or increased sensitivity to a uterine luteolysin. Plasma concentrations of the prostaglandin metabolite 15-keto-13,14-dihydro-PGF-2 $\alpha$ (PGFM) are elevated for the first 3 weeks post partum and thereafter decline (Fredriksson, 1985). Hysterectomy at Day 1 post partum hastens this fall in PGFM concentrations, confirming that prostaglandins from the post-partum uterus probably cause the high concentrations of PGFM in jugular plasma at this time (Lewis \& Bolt, 1987). Similarly, removal of the uterus maintains the luteal life-span (as determined by peripheral progesterone concentrations) of inadequate corpora lutea induced by GnRH therapy in seasonally anoestrous ewes (Southee et al., 1988) and of the first corpus luteum formed after early weaning in post-partum cows (Copelin et al., 1987). The majority of abnormal corpora lutea monitored in the present studies either fail completely to secrete progesterone or show a transitory increase lasting 24-36 h. Whether they are sufficiently advanced with respect to progesterone secretion to be sensitive to a uterine luteolysin remains to be established.

As lactation generally prolongs the interval from parturition to first oestrus in naturally ovulating ewes (Mauleon \& Dauzier, 1965; Mallampati et al., 1971; Fletcher, 1973; Shevah et al., 1975) we suggested that suckling-induced hyperprolactinaemia with its associated suppression of gonadotrophin secretion (see McNeilly, 1988, for review) would be detrimental to the establishment of functional corpora lutea in the post-partum ewe. However, we observed that during the non-breeding and breeding seasons the incidence of inadequate luteal function was marginally higher in early weaned than in lactating ewes, suggesting that the suckling stimulus per se does 
not contribute to abnormal luteal function. Rhind et al. (1977) reported a negative correlation between prolactin and progesterone concentrations during the first 11 days of pregnancy in Finn Dorset ewes induced to ovulate during seasonal anoestrus, but in the present studies we found no evidence to support a direct effect of high prolactin levels on progesterone secretion. Indeed, within the non-breeding and breeding seasons the progesterone concentrations for early weaned and lactating ewes were equivalent to those of standard ewes during the first 14 days of the induced oestrous cycle and were independent of stage post partum despite radically different prolactin backgrounds.

The results of Exp. 2 show that, for a number of early post-partum ewes that did not maintain a pregnancy following the receipt of embryos, peripheral progesterone concentrations were high beyond Day 18 of the cycle, suggesting that premature regression of the corpus luteum was not the only reason for pregnancy failure. The high incidence of pregnancy failure after the receipt of embryos would appear to be due to embryo mortality perhaps caused by an inappropriate uterine environment or the inability of the embryo to sustain its luteotrophic signal. This is supported by previous studies from this laboratory which showed that autotransfer of embryos recovered from lactating ewes induced to ovulate at Day 28 post partum and exhibiting normal luteal function failed to result in the establishment of pregnancy (McKelvey et al., 1989). In contrast, the transfer of embryos recovered from lactating ewes induced to ovulate as early as 24 days post partum into standard ewes, i.e. into a normal uterine environment, has resulted in the birth of viable lambs (J. M. Wallace, J. J. Robinson \& R. P. Aitken, unpublished observations). Data on the rate of uterine involution in the ewe are conflicting and rely on uterine weights obtained from sequential slaughter experiments. Honmode (1977) showed that involution was not completed until Day 35 in early weaned ewes and as late as Day 60 in lactating ewes. However, the majority of estimates suggest that involution is complete between 21 and 28 days post partum (Mallampati et al., 1971; Call et al., 1976; Schirar \& Martinet, 1982; Novoa, 1984). None of the ewes induced to ovulate on Day 21 post partum in Exp. 2 established pregnancies; however, as detritus was still being discharged from the uterus when they received embryos on Day 26 post partum it seems unlikely that involution was complete at this stage. Indeed, results of reciprocal embryo transfer studies between non-lactating and lactating ewes suggest that the uterine environment is still unfavourable for embryo development as late as 45 days post partum (Cognie et al., 1975).

Of the ewes that received embryos following induction of ovulation at 35 days post partum, the number of lambs born was very small. Nevertheless comparison of the birth weights of singleton lambs from standard post-partum ewes, expressed as $\mathrm{g} / \mathrm{kg}$ weight ${ }^{0.75}$ of the ewe at the time of transfer, showed that the values were more variable and, although marginally lower for lambs born from post-partum ewes $\left(231 \pm 28.9\right.$ versus $\left.247 \pm 7.6 \mathrm{~g} / \mathrm{kg}^{0.75}\right)$ were still above the values predicted from the data presented by Donald \& Russel (1970). There is therefore no real evidence that the prenatal growth processes of lambs born to ewes receiving embryos at Day 35 post partum were adversely affected by the uterine environment.

Communication between the maternal uterine environment and the embryo is known to be vitally important to the establishment of pregnancy in normally cycling ewes and is mediated via secretions from both the endometrium and the embryo (Bazer \& Roberts, 1983; Bazer et al., 1986). As yet we have no information on the biochemical nature of the endometrial/ conceptus secretions in the early post-partum ewe but it is possible that abnormal or asynchronous bi-directional signalling between them may be contributing to pregnancy failure in Exp. 2.

We thank Miss M. Cheyne, Miss S. Ireland and Mrs I. Robertson for skilled technical assistance; Mr D. Grubb for statistical analysis; the NIADDK and Dr A. S. McNeilly for hormone preparations and antiserum; and Professor I. Gordon, University College, Dublin, for CIDR devices. 


\section{References}

Bazer, F.W. \& Roberts, R. (1983) Biochemical aspects of conceptus-endometrial interactions. J. exp. Zool. 228, 373-383.

Bazer, F.W., Vallet, J.L., Roberts, R.M., Sharp, D.C. \& Thatcher, W.W. (1986) Role of conceptus secretory products in establishment of pregnancy. $J$. Reprod. Fert. 76, 841-850.

Call, J.W., Foote, W.C., Eckre, C.D. \& Hulet, C.V. (1976) Post-partum uterine and ovarian changes from oestrous behaviour from lactation effects in normal and hormone treated ewes. Theriogenology 6 , 495-501.

Cognie, Y. \& Pelletier, J. (1976) Preovulatory LH release and ovulation in dry and in lactating ewes after progestagen and PMSG treatment during the seasonal anoestrous. Annls Biol. anim. Biochim. Biophys. 16, $529-536$.

Cognie, Y., Hernande-Barreto, M. \& Saumande, J. (1975) Low fertility in nursing ewes during the non-breeding season. Annls Biol. anim. Biochim. Biophys. 15, 329-343.

Copelin, J.P., Smith, M.F., Garverick, H. A. \& Youngquist, R.S. (1987) Effect of the uterus on subnormal luteal function in anestrous beef cows. $J$. Anim. Sci. 64, 1506-1511.

Dawe, S.T. \& Fletcher, I.C. (1976) The effect of post lambing interval on fertilisation in lactating ewes treated with progestagen impregnated sponges and gonadotrophin. Proc. Aust. Soc. Anim. Prod. 11, $137-140$.

Djahanbahkch, O., Swanston, I.A., Corrie, J.E.T. \& McNeilly, A.S. (1981) Prediction of ovulation by progesterone. Lancet ii, 1164-1165.

Donald, H.P. \& Russel, W.S. (1970) The relationship between live weight of ewe at mating and weight of newborn lamb. Anim. Prod. 12, 273-280.

Fletcher, J.C. (1973) Effects of lactation, suckling and oxytocin on post-partum ovulation and oestrus in ewes. J. Reprod. Fert. 33, 293-298.

Fredriksson, G. (1985) Release of $\mathrm{PGF}_{2} \alpha$ during parturition and the postpartum period in the ewe. Theriogenology 24, 331-335.

Haresign, W. \& Lamming, G.E. (1978) Comparison of LH release and luteal function in cyclic and LH-RHtreated anoestrous ewes pretreated with PMSG or oestrogen. J. Reprod. Fert. 52, 349-353.

Honmode, D. (1977) Post-partum changes in the uterus of ewes. Anim. Breeding Abst. 45, 384 (Abstr. 3280).

Hunter, G.L., Adam, C.E. \& Rowson, L.E.A. (1955) Interbreed ovum transfer in sheep. J. agric. Sci., Camb. 46, 143-149.

Kann, G. \& Martinet, J. (1975) Prolactin levels and duration of post-partum anoestrus in lactating ewes. Nature, Lond. 257, 63-64.

Kann, G., Martinet, J. \& Schirar, A. (1977) Modifications of gonadotrophin secretion during natural and artificial hyperprolactinaemia in the ewe. In Prolactin and Human Reproduction, pp. 47-59. Eds P. G. Crosignani \& C. Robyn. Academic Press, London.

Lewis, G.S. \& Bolt, D.J. (1987) Effects of suckling, progestagen-impregnated pessaries or hysterectomy on ovarian function in autumn-lambing postpartum ewes. J. Anim. Sci. 64, 216-225.

Mallampati, R.G., Pope, A.L. \& Casida, L.E. (1971) Effects of suckling on postpartum anestrus in ewes lambing in different seasons of the year. J. Anim. Sci. 32, 673-677.

Mauleon, P. \& Dauzier, L. (1965) Variations de duree de l'anoestrus de lactation chez les brebis de race Ilede-France. Annls Biol. anim. Biochim. Biophys. 16, $521-528$.

McKelvey, W.A.C., Wallace, J.M., Robinson, J.J. \& Artken, R.P. (1989) Studies on increasing breeding frequency in the ewe. 1. The fertilization of ova during the early post-partum period. Anim. Reprod. Sci. (In Press).

McLeod, B.J., Haresign, W. \& Lamming, G.E. (1982a) Response of seasonally anoestrous ewes to small dose multiple injections of Gn-RH with and without progesterone pretreatment. J. Reprod. Fert. 65, 223-230.

McLeod, B.J., Haresign, W. \& Lamming, G.E. (1982b) The induction of ovulation and luteal function in seasonally anoestrous ewes treated with small-dose multiple injections of Gn-RH. J. Reprod. Fert. 65, 215-221.

McLeod, B.J., Haresign, W. \& Lamming, G.E. (1983) Induction of ovulation in seasonally anoestrous ewes by continuous infusion of low doses of GnRH. $J$. Reprod. Fert. 68, 489-495.

McNeilly, A.S. (1988) Suckling and the control of gonadotrophin secretion. In The Physiology of Reproduction, (in press). Eds E. Knobil \& J. D. Neill. Raven Press, New York.

McNeilly, A.S. \& Andrews, P. (1974) Purification and characterization of caprine prolactin. J. Endocr. 60, 359-367.

McNeilly, A.S., Hunter, M.G., Land, R.B. \& Fraser, H.M. (1981) Inadequate corpus luteum function after the induction of ovulation in anoestrous ewes by LH-RH or an LH-RH agonist. $J$. Reprod. Fert. 63, 137-144.

McNeilly, A.S., Jonassen, J.A. \& Fraser, H.M. (1986) Suppression of follicular development after chronic LHRH immunoneutralization in the ewe. J. Reprod. Fert. 76, 481-490.

Novoa, C. (1984) The postpartum ewe. Proc. 10th Int. Congr. Anim. Reprod. \& A.I., Urbana VII, pp. 24-30.

Quirke, J.F., Hanrahan, J.P., Sheehan, W. \& Gosling, J.P. (1981) Effect of lactation on some aspects of reproduction in progestagen-PMSG treated ewes during the non-breeding season. Irish J. agric. Res. $20,1-8$.

Restall, B.J., Kearins, R.D., Herdegen, J. \& Carberry, P. (1978) The induction of reproduction activity in lactating ewes. Aust. J. agric. Res. 29, 181-189.

Rhind, S.M., Robinson, J.J., Fraser, C. \& Phillippo, M. (1977) Effects of season and lactation on ovulation rate, plasma progesterone concentrations in early pregnancy and lamb production in Finnish Landrace $\times$ Dorset Horn ewes. Anim. Prod. 24, Abstr. 128 . 
Rhind, S.M., Robinson, J.J., Chesworth, J.M. \& Phillippo, M. (1980) The effects of season, lactation and plane of nutrition on the reproductive performance and associated plasma $\mathrm{LH}$ and progesterone profiles in hormonally treated ewes. J. Reprod. Fert. $58,127-137$.

Schirar, A. \& Martinet, J. (1982) Postpartum ovarian activity and its interaction with the uterus in resuming cyclic activity post partum. In Factors Influencing Fertility in the Postpartum Cow, pp. 67-94. Eds H. Karg \& E. Schallenberger. Martinus Nijhoff, The Hague.

Shevah, Y., Black, W.J.M., Carr, W.R. \& Land, R.B. (1975) The effect of lactation on the resumption of reproductive activity and the preovulatory release of LH in Finn $\times$ Dorset ewes. J. Reprod. Fert. 38, 369-378.

Southee, J.A., Hunter, M.G., Low, A. \& Haresign, W.
(1988) Effects of hysterectomy on the short lifecycle corpora lutea produced after GnRH-induced ovulation in the anoestrous ewe. J. Reprod. Fert. 84, 149-155.

Wallace, J.M., McNeilly, A.S. \& Baird, D.T. (1986) Induction of ovulation during anoestrus in two breeds of sheep with multiple injections of $\mathrm{LH}$ alone or in combination with FSH. J. Endocr. 111, 181-190.

Wallace, J.M., Robinson, J.J., McKelvey, W.A.C. \& Aitken, R.P. (1989) Studies on increasing breeding frequency in the ewe 2 . The endocrine status of lactating ewes induced to ovulate 28,35 or 42 days post-partum. Anim. Reprod. Sci. (In Press).

Wenham, G. \& Robinson, J. J. (1972) Radiographic pregnancy diagnosis in sheep. J. agric. Sci., Camb. 78, 233-238.

Received 6 June 1988 